\title{
LONGEVITY AND LIFE CYCLE SAVINGS
}

\author{
David E. Bloom \\ David Canning \\ Bryan Graham
}

Working Paper 8808

http://www.nber.org/papers/w8808

\author{
NATIONAL BUREAU OF ECONOMIC RESEARCH \\ 1050 Massachusetts Avenue \\ Cambridge, MA 02138 \\ March 2002
}

The authors would like to thank Angus Deaton, Allen Kelley, Andrew Mason, and Larry Rosenberg for helpful discussions and comments. An early version of this paper was presented at meetings of the World Health Organization's Commission on Macroeconomics and Health (Working Group One) and at a conference on demography and economic performance held at the Harvard University Center for Population and Development Studies. Financial support was provided from the Economic Advisory Service of the World Health Organization. The views expressed herein are those of the authors and not necessarily those of the National Bureau of Economic Research.

(C) 2002 by David E. Bloom, David Canning and Bryan Graham. All rights reserved. Short sections of text, not to exceed two paragraphs, may be quoted without explicit permission provided that full credit, including (C) notice, is given to the source. 
Longevity and Life Cycle Savings

David E. Bloom, David Canning and Bryan Graham

NBER Working Paper No. 8808

March 2002

JEL No. E21, I12

\begin{abstract}
We add health and longevity to a standard model of life cycle saving and show that, under plausible assumptions, increases in longevity lead to higher savings rates at every age, even when retirement is endogenous. In a stable population these higher savings rates are offset by increased old age dependency, but during the disequilibrium phase, when longevity is rising, the effect on aggregate savings rates can be substantial. Our results explain the boom in savings in East Asia during 1950-90 as a combination of rising life expectancy and falling youth dependency, though they predict that savings in the region will return to more normal levels as populations age. We also find that falling life expectancies in Africa are associated with declining savings rates.
\end{abstract}

$\begin{array}{lll}\text { David E. Bloom } & \text { David Canning } & \text { Bryan Graham } \\ \text { School of Public Health } & \text { Department of Economics } & \text { Department of Economics } \\ \text { Harvard University } & \text { Queen's University of Belfast } & \text { Harvard University } \\ \text { and NBER } & \text { d.canning@qub.ac.uk } & \text { bgraham@fas.harvard.edu } \\ \text { dbloom@hsph.harvard.edu } & 44-2890-273281 & 617-496-4665 \\ \text { 617-432-0654 } & & \end{array}$




\section{Introduction}

The savings rate is among the most studied macroeconomic aggregates, reflecting its importance for understanding a wide range of economic phenomena. How much society chooses to save today for consumption tomorrow has important implications for the welfare of the elderly, economic growth, and consumption levels. Savings rates differ across countries and across time within countries, often dramatically. The benchmark model for explaining these differences has been the life cycle model of savings.

According to the life cycle model of savings people save when young to finance consumption during retirement. In theory (in the absence of a bequest motive), the dissaving of the old should offset the saving of the young, so that in a stable population there is no aggregate saving. However, if the age structure of the population is unbalanced, as occurs during a demographic transition, the saving behaviors of different cohorts may not cancel out, and aggregate savings, or dissavings, may occur. In addition, Fry and Mason $(1982)$ and Mason $(1981,1987,1988)$ point out that in economies undergoing rapid economic growth the wage incomes of the young are high relative to the retirement incomes of the old (which were saved out of past, lower wages), and this relative concentration of income among the high savings rate group should generate positive aggregate savings. Investigators have studied these age structure and growth effects extensively (see, for example, Higgins 1998; Higgins and Williamson 1997; Kelley and Schmidt 1996; Leff 1969; Masson, Bayoumi, and Samiei 1998), and have found that, in general, national savings rates are higher when dependency rates are low and economic growth is rapid. 
While the empirical evidence tends to support the main predictions of the life cycle theory, a number of puzzles remain, in particular the extraordinary increase in national savings rates observed in East Asia between 1950 and 1990. Such large swings in savings are difficult to explain in the context of the standard life cycle model. Changes in the age structure of the population and in the distribution of income between cohorts account for only a small part of this upswing in saving. Household data from East Asia indicate that the major factor driving the surge was an increase in the rate of saving at every age (see Deaton 1992 for Thailand and Deaton and Paxson 1993, 1997, 1998 for Taiwan). Such across the board savings surges cannot be reconciled with standard life cycle theory.

Recently Lee, Mason, and Miller $(1998,2000)$ have suggested that the reason for this surge in savings was the rapidly improving life expectancy in the region. By calibrating a simulation model with a fixed retirement age, they argue that the need to finance a longer period of retirement can account for the surge in savings.

The aim of this paper is to investigate empirically whether changes in longevity play an important role in determining national savings. While the paper focuses on savings, it is part of a larger literature that is re-evaluating the role of health and life expectancy on economic behavior (Bils and Klenow 2000; Bloom and Canning 2000, Bloom and Canning 2001; Kalemli-Ozcan, Ryder, and Weil 1998; Meltzer 1995; Strauss and Thomas 1998).

We begin by investigating the role of longevity in a dynamic optimization model of life cycle savings. We take decisions to participate in the labor market to be endogenous, allowing agents to choose their retirement age. Under the assumption that 
consumption and leisure are normal goods, so that the demand for both rises when wealth increases, we show that a rise in life expectancy increases the optimal fraction of life spent working, but not by enough to offset the increased need for retirement income. Therefore savings rates rise at every age as longevity rises in order to meet the increased need for assets to finance consumption during retirement. However, increased longevity is likely to go hand in hand with general health improvements that may increase the productivity and wages of the elderly, giving an incentive to postpone retirement. For example, Fogel $(1994,1997)$ argues that not only has life expectancy increased, but disability among the aged has also declined dramatically in the United States over the last 100 years. Health improvements that both increase longevity and reduce morbidity may allow a sufficient increase in the length of working life to allow savings rates to fall.

Ideally, we would like to separate out the effects of increased longevity from those of reduced morbidity. However, in the absence of comprehensive data on ill health we use life expectancy as a measure of health in general that proxies for both longevity and lack of disability. It follows that while the pure effect of improved longevity on savings is positive, in practice it will be a proxy for general improvements in health, and its overall effect on optimal savings is ambiguous.

We construct an empirical model of aggregate savings that includes longevity as a determinant and estimate it using cross-country panel data. While the inclusion of life expectancy in models of aggregate savings is rare, it has been used on occasion and found to have a positive effect (see, for example, Asian Development Bank 1997; Doshi 1994). We aim to improve upon these empirical studies in a number of ways. First, we tackle the issue of how to incorporate age structure effects. While Kelley and Schmidt 
(1996) and Leff (1969) use young and old age dependency rates to model age structure, Higgins (1998) allows the size of each five-year age cohort to have an effect, although he constrains these effects to lie on a cubic function for estimation purposes. We employ an encompassing model, but find that using dependency rates fits the data better than a cubic in age and has the advantage of being much easier to interpret.

Second, while we might expect savings rates to rise with longevity, important nonlinearities may be present in the relationship. We investigate these by allowing for a nonlinear functional form and by separating life expectancy into discreet (five-year) bands and estimating the effect on savings of moving between bands. We find some evidence that savings increase sharply with life expectancy up to about age 65 , but that the effect then levels off.

Third, in addition to the need to smooth consumption over the life cycle, a number of other factors also affect the savings decision. Credit constraints may mean that borrowing and aggregate savings rates depend on the level of income. Habit formation in relation to consumption may boost savings during periods of rapid income growth. Mandatory pay-as-you-go pension schemes mean that consumption during retirement may be financed by transfers from the young, thereby reducing the need for life cycle savings. In developing countries where people tend to have large families the elderly may rely more on intra-household transfers and less on savings as a method of old age support. Savings rates may also depend on the availability of financial markets and may be influenced by the likelihood of inflation, which could erode the value of financial assets. To account for these factors we include a range of additional variables and use fixed effects to control for institutional and cultural differences across countries. 
Our results agree with the ideas put forward by Lee, Mason, and Miller (2000), namely, that increases in life expectancy play a large role in savings behavior, and in particular explain the observed surge in savings in East Asia. They also complement the results of Hurd, McFadden and Gan (1998) who find evidence using US household data that people with higher subjective survival probabilities save more.

While increases in longevity may increase the savings rate at every age, the effect on aggregate savings is transitory. Increases in longevity imply that the stable age structure has a higher proportion of elderly, and that in the long run higher age-specific saving rates are offset by greater numbers of elderly who are dissaving (note that this balancing effect may take 50 years or more to come about). The effects of increases in life expectancy in East Asia on saving may be great, but our theory suggests that they will dissipate as the population ages.

The life cycle theory of saving predicts that in a stable population with no economic growth, net savings will be zero. This suggests that models that include age structure effects but not longevity are misspecified. High rates of old age dependency need not reduce overall savings if they are associated with high levels of life expectancy and the dis-savings of the old are matched by the savings of the young for their retirement. According to our theory, only age structures that are in dis-equilibrium, given current life expectancy, will affect aggregate savings, but standard models of age structure effects do not distinguish between stable populations and dis-equilibrium age structures. The fact that many countries have close to stable populations tends to drive the age structure effects in these models toward zero. Adding longevity to the relationship allows us to uncover the large effects on savings rates that occur when the age structures 
change at a given life expectancy (for example, because of changes in fertility) and when health improves and life expectancy rises within a given population age structure.

\section{Theory}

We assume that agents maximize their utility over their lifetimes, choosing how much to work and how much to consume, and investigate how changing life expectancy affects their choice. We follow Bils and Klenow (2000) and Meltzer (1995), who study investments in education, and assume that agents have a known lifetime, $\mathrm{T}$.

For simplicity we assume that longevity is fixed exogenously, ignoring the possibility that it is linked to consumption and to spending on health care (see, for instance, Philipson and Becker 1998 for an analysis that allows health status and longevity to be endogenous). We also ignore any effects of uncertainty about the timing of death, effects that may be important (see, for example, Leung 1994, Kalemli-Ozcan and Weil 2002).

We assume that agents seek to maximize lifetime utility given by

$$
\int_{0}^{T} e^{-\delta t} U\left(c_{t}, l_{t}, h_{t}\right) d t
$$

where $\mathrm{c}$ is consumption, $l$ is leisure, $\mathrm{h}$ is health, and $\delta$ is their discount rate and the index $t$ is age. We assume that the time path of health is exogenously fixed. Agents choose their leisure and consumption paths subject to the constraints

$$
c_{t} \geq 0, \quad 1 \geq l_{t} \geq 0, \quad W_{T} \geq 0
$$

where the stock of wealth, $\mathrm{W}_{\mathrm{t}}$, evolves according to 


$$
\frac{d W_{t}}{d t}=r W_{t}+\left(1-l_{t}\right) w_{t}-c_{t}
$$

We assume that the time path of wages, $\mathrm{w}_{\mathrm{t}}$, the interest rate, $\mathrm{r}$, and the initial stock of wealth, $\mathrm{W}_{0}$, are fixed exogenously. Equation (2.3) gives the savings (the addition to wealth) of the agent.

Assuming that the instantaneous utility function $\mathrm{U}$ is increasing and strictly concave in each argument, it is straightforward to show (by forming the Hamiltonian and applying the maximum principle - see, for example, Berck and Sydaeter 1992), that the optimal path of consumption and leisure satisfies

$$
\frac{d c}{d t}=\frac{(r-\delta) \frac{d U}{d c}+\frac{d^{2} U}{d c d l} \frac{d l}{d t}+\frac{d^{2} U}{d c d h} \frac{d h}{d t}}{-\frac{d^{2} U}{d c^{2}}}
$$

and

$$
\frac{d U}{d l_{t}}=w_{t} \frac{d U}{d c_{t}} \text { if } 1<l<0, \quad \frac{d U}{d l_{t}} \geq w_{t} \frac{d U}{d c_{t}} \text { if } l=1, \quad \frac{d U}{d l_{t}} \leq w_{t} \frac{d U}{d c_{t}} \text { if } l=0
$$

Agents work up to the point where their marginal utility of extra leisure equals the marginal utility of the consumption goods they could purchase if they worked.

Retirement occurs ( $l=1)$ when the marginal utility of leisure, even with no work, exceeds the marginal utility of consumption times the wage rate. Let us denote the optimal plan by $\left(c_{t}^{*}, l_{t}^{*}\right)$, which produces the time path of net wealth holdings $W_{t}^{*}$. The declining marginal utility of consumption means that the bottom line of equation (2.4) is positive. The time path of consumption depends on the rate of time preference and the complementarity of consumption with leisure and health. 
Consumption will tend to rise over time if the interest rate exceeds the rate of time preference.

As it stands, the model does not imply that people ever retire. For retirement to take place we need the wage rate to decline or the utility of leisure to rise as people age. For example, if people's health declines over time, this may lower their productivity and wages. In addition, if health and leisure are complements (so that lowering health raises the disutility of working), this may increase the marginal utility of leisure. It seems reasonable to make assumptions about preferences and wage rates such that people plan to retire at some point and that they save for this retirement - making our model compatible with the life cycle model of saving.

We make two assumptions. The first assumption (assumption 1) is that, given initial wealth holdings of zero at the start of life, the optimal path (for any T) has $W_{t}^{*} \geq 0$ for all $0 \leq t \leq T$. This implies that people never go into debt to finance consumption. Sufficient conditions to ensure this are quite easy to find. For example, if the wage rate falls over time while the marginal utility of leisure increases, work and earnings will be concentrated in the early part of life. Provided $r$ is large enough, so that consumption is level or skewed toward the end of life, the concentration of earnings when young and the need for consumption when old will ensure positive wealth holdings at all times. Rather than impose conditions on the utility function and wage profile that ensure people save for retirement, it seems easier to assume 1 directly.

We also assume (assumption 2) that both consumption and leisure are normal goods, that is, 


$$
\frac{d c_{t}^{*}}{d W_{0}} \geq 0, \frac{d l_{t}^{*}}{d W_{0}} \geq 0, \text { for all } 0 \leq t \leq T
$$

We assume that an increase in initial wealth increases consumption and leisure at all times. The alternative would be that an increase in wealth causes people to decrease their hours of work to such an extent that their optimal consumption falls or to increase consumption to such an extent that their leisure time falls. While these outcomes are possible, they seem unlikely. Now consider what happens to the agents' optimal plan when we increase longevity, keeping everything else the same. We are particularly interested in the savings rate defined as

$$
s_{t}=\frac{y_{t}-c_{t}}{y_{t}}, \text { where } y_{t}=r W_{t}+\left(1-l_{t}\right) w_{t}
$$

Our proposition is: let $W_{0}=0$. Under assumptions 1 and 2 an increase in longevity increases the savings rate at every age.

Our proof goes as follows. Let $\left(c_{t}^{*}, l_{t}^{*}\right)$ be the original optimal plan for life expectancy $\mathrm{T}$, and let $\left(c_{t}^{* *}, l_{t}^{* *}\right)$ be the new optimal plan when life expectancy rises. By assumption 1, wealth at time $\mathrm{T}$ in the new optimal plan is non-negative, that is, $W_{T}^{* *} \geq 0$. Now let us keep behavior after $\mathrm{T}$ fixed and restrict our attention to the time interval $[0, T]$. As the new optimal plan cannot be improved upon, it maximizes

$$
\int_{0}^{T} e^{-\delta t} U\left(c_{t}, l_{t}, h_{t}\right) d t
$$

subject to

$$
c_{t} \geq 0, \quad 1 \geq l_{t} \geq 0, \quad W_{T} \geq W_{T}^{* *}
$$


However, this is the same problem, and has the same solution, as maximizing over $[0, \mathrm{~T}]$ subject to

$$
c_{t} \geq 0, \quad 1 \geq l_{t} \geq 0, \quad W_{T} \geq 0
$$

but with $W_{0}=-W_{T}^{* *} e^{-r T}$. This is the original problem of maximizing over [0, T], but with lower initial wealth. By assumption 2, it follows that on $[0, \mathrm{~T}]$ we have $c_{t}^{* *} \leq c_{t}^{*}, l_{t}^{* *} \leq l_{t}^{*}$. Using equation (2.7) it is easy to show that the savings rate is increasing in y and decreasing in $\mathrm{c}$, and it follows immediately that $s_{0}^{* *} \geq s_{0}^{*}$. At each point in time, wage income under the new plan is higher than before and consumption is lower. By equation (2.3), wealth accumulates more quickly under the new plan, and as time passes, interest payments on the rising stock of wealth compound this effect. It follows that at every point in time income under the new plan is higher, and consumption is lower, giving a higher savings rate.

The rise in savings rates at every age is consistent with the evidence on household consumption in Taiwan and Thailand, where the boom in savings was caused by an upward shift of the entire age-specific savings rate schedule.

The proposition deals with a pure increase in longevity, with no improvement in health status as people age. In practice, increases in longevity will be associated with better overall health, and empirical regressions will pick up both effects if we do not control for morbidity separately.

Suppose that longevity increases from $T$ to $T^{\prime}=\lambda T$, but at the same time health status improves by delaying the onset of the effects of aging proportionately. This implies 
that productivity and health status stay higher longer, and we have $w_{\lambda t}^{\prime}=w_{t}, h_{\lambda t}^{\prime}=h_{t}$.

With these proportional health and longevity improvements agents maximize

$$
\int_{0}^{T^{\prime}} e^{-\delta t} U\left(c_{t}, l_{t}, h_{t}^{\prime}\right) d t
$$

subject to

$$
c_{t} \geq 0, \quad 1 \geq l_{t} \geq 0, \quad W_{T^{\prime}} \geq 0, \quad \frac{d W_{t}}{d t}=r W_{t}+\left(1-l_{t}\right) w_{t}^{\prime}-c_{t}
$$

By a simple change of variable $\left(z=t / \lambda, K_{z}=W_{t} / \lambda\right)$ we can show that this is equivalent to choosing the time paths $\mathrm{c}$ and 1 so as to maximize

$$
\lambda \int_{0}^{T} e^{-\lambda \delta z} U\left(c_{z}, l_{z}, h_{z}\right) d z
$$

subject to

$$
c_{z} \geq 0, \quad 1 \geq l_{z} \geq 0, \quad K_{T} \geq 0, \quad \frac{d K_{z}}{d z}=\lambda r K_{z}+\left(1-l_{z}\right) w_{z}-c_{z}
$$

It is easy to see that if $r=\delta=0$ the new maximization problem is identical to the original problem, except that the objective function is multiplied by $\lambda$. This has the same solution as the original problem, and means that the optimal decisions at time $\lambda t$ in the new problem are the same as those at time t originally. For example, if agents save at a constant rate until retirement, the effect of increasing longevity and improving health together is that agents extend their working lives proportionately and save at exactly the same rate as before. Note, however, that in equations (2.10) and (2.11) this proportionality result depends on the interest rate and the rate of time preference being zero. If these are positive, the longer time horizon in itself can have real effects on saving. The longer horizon gives a greater time for the benefits of compound interest to 
become apparent, and is formally equivalent to an equal increase in the rate of interest and rate of time preference in the original model. This will tend to increase the planned growth rate of consumption (and increase the savings of the young) if the interest rate exceeds the rate of time preference.

More generally, an improvement in longevity may be associated with a greater or less than proportional improvement in health status at each age. Our simple theory suggests that the pure effect of greater longevity is to increase savings rates, but that if the increased longevity is associated with better health when old, and in particular with higher productivity and lower disutility of work than before, the effect is ambiguous.

In practice, our simple life cycle theory faces many challenges. Institutional arrangements in many countries mandate retirement between the ages of 60 and 65. These may mean that increases in longevity lead to increases in savings rates even if health also improves (Lee and Tulijapurkar 1997). The need for savings may, however, be reduced in countries with social security systems that provide transfer payments to the old. Likewise, transfers within families may support people in their old age, reducing the need for savings.

We try to take account of these institutional and cultural differences across countries by allowing for country fixed effects in our estimation. In addition we allow the magnitude of life cycle savings to depend on a county's income level to allow for the possibility that the importance of life cycle saving varies with the level of development. 


\section{Data}

There are several conceptually different measures of aggregate savings. We start with the following identity:

$$
\mathrm{Y}=\mathrm{C}+\mathrm{I}+\mathrm{G}+(\mathrm{X}-\mathrm{M})
$$

where $\mathrm{Y}$ is gross domestic product (GDP), $\mathrm{C}$ is private consumption, $\mathrm{I}$ is gross investment (private plus public), $\mathrm{G}$ is government consumption, and (X - M) is net exports (the trade balance). Gross domestic savings (GDS) is the sum of public and private savings. Letting $\mathrm{T}$ be tax revenues, $\mathrm{T}-\mathrm{G}$ is public savings and $\mathrm{Y}-\mathrm{C}-\mathrm{T}$ is private savings. Thus,

$$
\mathrm{GDS}=\mathrm{Y}-\mathrm{C}-\mathrm{G}=\mathrm{I}+(\mathrm{X}-\mathrm{M})
$$

so that GDS equals gross income that is not consumed, or in terms of the accumulation of wealth, gross investment plus net acquisition of foreign assets. The gross domestic savings rate is GDS/Y.

Our source for GDS is the World Development Indicators 1999 (World Bank 1999), which includes annual data from 1960 to 1997. Gross domestic income only measures the value of income generated by economic activity within a country. People living within a country will also receive income from their ownership of foreign assets and may receive transfer payments from abroad. Gross national product (GNP) is given by GNP $=\mathrm{Y}+\mathrm{NFI}$, where NFI is net factor income from abroad plus international transfers (for instance, net foreign aid inflows and net remittance inflows from overseas workers). This yields gross national savings (GNS) as follows:

$$
\mathrm{GNS}=\mathrm{Y}+\mathrm{NFI}-\mathrm{C}-\mathrm{G}=\mathrm{GDS}+\mathrm{NFI}
$$


The gross national savings rate is GNS/GNP. Conceptually, gross national savings is a superior measure than gross domestic savings, because it reflects total income, independent of its source. Data on gross national savings are available from World Development Indicators 1999, but only from 1970 onwards. In addition to the reported gross national savings rates, we can calculate an alternative measure of gross national savings from 1960 to 1997 using income, savings, and data on net factor income from abroad contained in the World Development Indicators 1999. This has the advantage of wider data coverage but has the drawback that it excludes international transfer payments.

This gives us three measures of the savings rate: GDS, GNS properly measured from 1970, and a GNS measure that excludes international transfer payments from 1960. Savings are quite volatile from year to year, and we follow Higgins (1998) and average over successive five-year intervals to smooth out business cycle effects.

These measures fall far short of theoretically correct measures of savings for a number of reasons. First, GDS and GNP are gross measures. Conceptually, a net measure that subtracts an allowance for the depreciation of capital from both income and gross investment would be superior. Second, income from the depletion of natural resources actually involves a running down of capital stocks and represents dissaving. Finally, income should include capital gains on a country's stock of physical capital, overseas assets, and natural resources. However, the lack of suitable data means that we are limited to our imperfect gross savings measures. When we measure aggregate savings we have not only household savings, but also government savings and profit retention by the corporate sector. However, these additional forms of saving will not affect total savings if 
households, who are their ultimate owners, count these forms of saving as part of their own savings.

In our analysis we exclude socialist countries because in these cases savings and investment are controlled almost entirely by the public sector; we have no reason to expect their savings behavior to fit the optimizing life cycle model. We also exclude countries with populations of less than 1 million, and major oil producers (with a value of oil production in excess of $2.5 \%$ of GDP) because we do not take account of the extremely large capital gains and losses caused by changes in oil prices that dominate the economies of these countries.

Table 1 presents the definitions, sources, and coverage of the savings rate data used in this study. Table 2 provides simple descriptive statistics on the different savings rate variables, and shows that the means, standard deviations, and maximums are reasonably comparable across measures. In table 3 we report the correlations between the different savings rate measures. While the GDS and $\mathrm{GNS}_{\mathrm{II}}$ data are highly correlated, $\mathrm{GNS}_{\text {I }}$ has a correlation significantly less than one, indicating that taking account of international transfer payments significantly affects our measure of savings.

Table 4 provides some simple descriptive statistics on the explanatory variables we use. Demographic data on life expectancy and age structure come from the United Nations (1998). Real income per capita and the GDP deflator are from Penn World Tables (5.6), (See Summers and Heston (1991) for a description of this data set.) The ratio of liquid liabilities to GDP is from International Economic Data Base (1997).

[insert tables 1, 2, 3, and 4 about here] 


\section{Explaining Aggregate Savings}

The average savings rate can be written as the sum of the savings rate of the different age groups in a population weighted by their income shares. That is, the average savings rate is

$$
\bar{s}=\sum_{i=0}^{T} s_{i} \frac{Y_{i}}{Y}=\sum_{i=0}^{T} s_{i} \frac{P_{i}}{P} \frac{y_{i}}{\bar{y}}
$$

where $s_{i}$ is the savings rate of age group $i$ and $Y_{i} / Y$ is its share of total income. A group's share of income can be further decomposed into its share of total population, $\mathrm{P}_{\mathrm{i}} / \mathrm{P}$, and the average income of its members as a proportion of the average income of the

population, $y_{i} / \bar{y}$. This implies that the age structure of the population matters. In addition, to the extent that growth changes the distribution of income between cohorts it will affect the savings rate. This effect is likely to go in different directions for different cohorts, implying that the growth rate effect enters interactively with the age structure. However, based on the proposition stated above, the effect of increased longevity is to raise the savings rate of every age group, which suggests that we can simply add some function of life expectancy to the relationship.

Table 5 reports simple regressions where we explain the gross domestic savings rate averaged over a 5-year period, using economic growth for the previous 10 years, and life expectancy and some age structure variables measured at the beginning of the period. That is, we measure the age structure effects in equation (4.1) directly, while the distribution of average income between cohorts depends on the growth rate and the age- 
specific savings rate depends on life expectancy (which proxies for both longevity and overall health status). Our theoretical model in section 2 also suggests that the real interest rate should play a role. However, in common with most empirical work we find little effect of interest rates on savings (see, for example, Higgins 1998), and for the sake of simplicity we exclude it.

[insert table 5 about here]

Column (1) of table 5 reports a regression that includes life expectancy, the growth rate of income, and 17 population age groups (by 5-year intervals from zero to 84). Note that in column (1) we do not report the individual cohort effects. Both life expectancy and economic growth appear to have positive and statistically significant effects on the average savings rate. While we do not report the individual cohort effects, we can reject the hypothesis that they are all zero (the F test at the bottom of column (1)). While the age structure matters, for tractability we want to compress the age structure effects into a smaller number of parameters. In column (2) we estimate a restricted model, where the coefficients on age structure are constrained to lie on a cubic equation (that is, the coefficient on the population share of cohort i, $\phi_{i}$ say, can be written as $\phi_{i}=\alpha_{0}+\alpha_{1} i+\alpha_{2} i^{2}+\alpha_{3} i^{3}$ ) with the addition of a step function, with steps at ages 20 and 60. This encompasses the dependency approach used, for example, by Kelley and Schmidt (1996) and the flexible function approach used by Higgins (1998).

Experimentation showed that splits at 20 and 60 performed better than the conventional 
dependency rate taken as $0-14$ and $65+$. In addition, adding a further step at 40 did not significantly improve the fit of the step function approach.

A test of the restrictions implied on the age structure effects when using the cubic functional form plus the dependency rate approach does not reject these restrictions (the F test at the bottom of column (2)). It follows that the data accept these restrictions and we can reduce the number of age effect parameters to be estimated.

We can go further and test whether both the cubic functional form and the dependency rate step function are required. Column (3) reports a model where the age structure effects are modeled as lying on a cubic function alone. Now both the linear and squared terms become statistically significant. The age effects are close to an inverse U, with young and old cohorts depressing savings and the middle age groups increasing the savings rate. However, an $\mathrm{F}$ test of the hypothesis that the dependency rate parameters are jointly zero (bottom of column (3) is rejected. Thus the combined model appears to fit the data better than the cubic function alone.

In column (4) we estimate the relationship allowing only the dependency rate effects of age structure. We find that the presence of large proportions of elderly or young people in the population depresses the savings rate, with the effect of the old being particularly large. Now, however, we cannot reject the exclusion of the cubic age effects (F test at the bottom of column (4)). Thus the age structure effects can be modeled adequately by the effects of the dependency rates, and we do not require polynomial age structure effects.

Table 6 repeats the analysis carried out in table 5, but adds fixed effects to capture any country-specific effects that may affect savings rates. Despite the addition of fixed 
effects, the results in table 6 are remarkably similar to those in table 5. Life expectancy again has a positive and significant effect, with a 10-year increase in longevity being associated with a rise in savings rates of about 4.5 percentage points. In addition, our tests on how to model the age structure effects follow a similar pattern to those in table 5 . The data accept the simplification of the age structure effects to the encompassing model and then to the dependency rate model, but not to the cubic functional form. We take the model with dependency rate effects as our base model and our starting point for further investigations.

[insert table 6 about here]

So far we have assumed that the age structure effect is linear, but there is no reason for this to be so. For example, if retirement at age 65 is mandatory or conventional, we might expect life expectancy in excess of 65 to have a greater impact on savings than life expectancy increases before 65 . In column (1) of table 7 we add two life expectancy variables: life expectancy itself and life expectancy when it is greater or equal to 65 . We find that the coefficient on life expectancy in excess of 65 is negative, though not significant. This suggests that increasing life expectancy past 65 has less impact on the savings rate than increases below 65 .

[insert table 7 about here] 
In column (2) of table 7 we repeat the estimation with fixed effects. In this case the post-65 variable has a coefficient close to zero. We also tried using a life expectancy squared term and found a similar pattern of falling impact of increasing life expectancy as life expectancy rises.

In column (3) of table 7 we report the results of grouping life expectancy into five-year intervals and estimating separately the impact of each life expectancy grouping on the savings rate. The estimated coefficients are graphed as a function of life expectancy in figure 1 . We can see a pattern of savings rising rapidly with life expectancy up to about age 65 , but then being fairly flat. The result remains similar when we add fixed effects in regression (4).

[insert figure 1 about here]

These results suggest that the response of savings to life expectancy may be quite complex. Life expectancy may be having an effect on the savings rate, in addition to the longevity effect, through changes in uncertainty or associated changes in morbidity. In addition, life expectancy data is very sensitive to infant mortality rates, while in practice it is the future survival prospects of the agent (conditional on their current age) that matters for saving decisions. The results, however, suggest that the largest impact of increases in longevity on savings rates may occur early in the development process when life expectancy is low.

In table 8 we test the model's robustness by adding a number of additional control variables. One possible complication is that the effect of economic growth and age 
structure on savings behavior may be interactive. Economic growth increases the relative incomes of the young and so not only increases average savings but increases the effect of a large young cohort. This leads to "growth tilting" (a tilt in the relationship between population age shares and overall savings rates) so that the impact of a large young cohort on savings is larger in a fast-growing economy. In regression (1) we add the interactive terms between economic growth and the dependency rates that are implied by growth tilting. Both interactive terms are negative and significant, implying that, as predicted, the impact of economic growth on the savings rate is highest when a large share of the population is of working age. In column (2) of table 8 we add the log of income per capita (in purchasing power parity terms). Countries with high income per capita will usually have high wage rates. High wages have both an income and a substitution effect on labor supply decisions and the retirement age. For example, if the income effect dominates, people will want more leisure and will retire earlier and have to save more for retirement. By contrast, if the substitution effect dominates, higher wages may induce people to work for longer, thereby reducing the need for retirement income and savings. We find that savings rise with the level of income per capita, and the estimate of the effect of life expectancy on savings, though still statistically significant, is somewhat reduced.

[insert table 8 about here]

In column (3) we add liquid liabilities as a percentage of GDP and the rate of inflation as explanatory variables. The ratio of liquid liabilities to GDP is a measure of 
the relative size of the financial system and may indicate opportunities for saving. While we have not included the real interest rate, periods of high inflation tend to be associated with a highly negative real rate of interest and a flight from financial. However, in practice neither of these variables seems to play a significant role in determining savings behavior.

In column (2) of table 8 we added log income per capita. In column (4) we add income per capita interactively with the life cycle model. This allows for the idea that the importance of life cycle savings depends on the level of development, proxied by a country's income level. Life cycle saving is multiplied by

$$
1+\beta \log \frac{y}{y_{\max }}
$$

where $\mathrm{y}$ is income per capita and $y_{\max }$ is the highest income per capita in the sample. The positive estimate of $\beta$ suggests that life cycle saving is more important in richer countries, likely because in poorer countries people rely more heavily on family support structures.

A serious problem with the results in table 8 is the potential for reverse causation from the savings rate to the level of income and the growth rate of income. For example, in many growth studies the savings rate is the key variable that affects the pace of economic growth and the steady-state level of income. Even though we measure income at the start of the 5-year period over which we average the savings rate and measure income growth over the previous 10 years, there is still the problem that the savings rate may be correlated over time so that it can be correlated with lagged income and lagged growth purely though a feedback effect. In addition, as well as a feedback from savings 
to income, there is potentially a feedback from income to health, implying that higher savings may be giving rise to higher life expectancy.

To deal with this issue we use an instrumental variable approach, treating income levels and growth rates, and life expectancy, as potentially endogenous. The results are reported in table 9. The instruments we use are latitude, percentage of land area within 100 kilometers of the coast or a major waterway, and percentage of land area in the tropics. Gallup, Sachs, and Mellinger (1999) argue that these geographical factors are major forces in determining both the level of income and the rate of growth. In addition, Bloom and Sachs (1998) argue that tropical location is a major contributory factor in ill health and premature death. These variables are good instruments in the sense that they predict both income level and life expectancy quite well, and it is difficult to see how they could affect savings directly, rather than through their effects on income and health. ${ }^{2}$

[insert table 9 about here]

In column (1) of table 9 we report our simple regression, but instrument the growth rate of income per capita. When we instrument the growth rate of income it changes sign from a positive effect to a negative effect. In column (2) we instrument both the growth rate of income and the level of life expectancy. While the coefficient on growth is still negative, the coefficient on life expectancy stays positive and significant. In column (3) we again instrument income growth, but allow for interactive effects and growth tilting. The results are now more in line with theory: economic growth increases 
the savings rate, particularly when a large share of the population is of working age. In column (4) we add the level of income per capita to the regression, but instrument it (and the growth rate of income). Income per capita no longer has a significant impact on the savings rate when we instrument it. The same holds true in column (5) of table 9 where we interact the level of income with the life cycle savings model, using the formula given in equation (4.2). Once again the effect of the level of income on the savings rate is not significant when it is instrumented. These results suggest that while the effects of life expectancy on the savings rate and the "growth tilting" effect are robust to using instruments, the effects of the level of income on saving are not robust. ${ }^{3}$

Throughout the analysis we have used gross domestic savings as our savings measure. In table 10 we report the coefficients on life expectancy we obtain by replicating our analysis using different measures of the savings rate. In each case the regressions include income growth and the youth and old age dependency rates, as well as a set of time dummies. Column (1) of table 10 reports ordinary least squares (OLS) results, while column (2) includes fixed effects and column (3) instruments the growth rate of income. For all for savings measures both the OLS and instrumental variable regressions give coefficients on life expectancy that are positive and statistically significant. However, the fixed effects regressions only find statistically significant results for life expectancy when we use the gross domestic savings rate at local prices and our constructed measure of gross national savings. Using the World Bank's measure of

\footnotetext{
${ }^{2}$ Geography might affect the marginal product of capital and the equilibrium interest rate, and so have an effect on the savings rate. However, a much more likely scenario is that the stock of capital will adjust to equalize its marginal productivity across geographical zones.

${ }^{3}$ The coefficient on the income variable is estimated with very little precision when we use instrumental variables. Thus while it is not significantly different from zero, it is also not significantly different from the coefficient in the un-instrumented estimates. Our data lack the required exogenous variation to precisely determine the magnitude of this coefficient.
} 
gross national savings (limited to the period 1970 onwards), life expectancy loses its significance with fixed effects. This anomalous result could be due to the shorter time span for which the World Bank data are available (i.e., 1970 to 1997). ${ }^{4}$

[insert table 10 about here]

Our model predicts a boost to savings when life expectancy increases, but this boost is temporary and is subsequently offset by a rising old age dependency rate as people age. The life-cycle model predicts that when the age structure reaches equilibrium, net savings should be zero. Figure 2 shows the empirical relationship between life expectancy and the youth and old age dependency rates in 1990. As we would expect, higher life expectancy is associated with higher old age dependency; however, it is also associated with a much lower youth dependency rate. To some extent this is the result of greater survival into older age groups, but it also reflects the low fertility rates that are common in countries with low mortality rates. Thus the model predicts a boom in savings during demographic transitions when life expectancy rises but old age dependency is still low.

[insert figure 2 about here]

In figure 3 we plot actual and predicted savings rates for our cross-section of countries in 1990 based on the results in regression (3) of table 9. This allows for life

\footnotetext{
${ }^{4}$ The fixed effects approach removes the effect of cross-country differences in life expectancy and depends only on the impact of changes in life expectancy over time.
} 
expectancy, age structure, and growth tilting effects, as well as worldwide time dummies. It does not include fixed effects, so the model has to predict the average level of the savings rate as well as how it changes over time. The model seems to perform fairly well, even without fixed effects.

[insert figure 3 about here]

We now investigate how good the model is at picking up the time path of savings. In figure 4 we plot the actual and predicted savings rates for a number of countries, again based on regression (3) of table 9. The model seems to perform fairly well in picking up both the level and time trends of the savings rate in the East Asian economies with high savings rates: Hong Kong, Japan, the Republic of Korea, Singapore, and Thailand. Rising life expectancy and falling youth dependency rates combine to give a rising predicted savings rate in Korea and Singapore, and to a lesser extent in Thailand. By contrast, both Hong Kong and Japan saw substantial increases in the old age dependency rate after 1980, which stabilized predicted savings in Hong Kong and actually leads to a fall in predicted savings in Japan.

[insert figure 4 about here]

We also look at Uganda, which provides an interesting contrast because after rising slowly, life expectancy fell sharply after 1980, and by 1990 was only 41. During the same period Uganda's youth dependency rate was stable at around 50 percent, while 
the number of old age dependents was negligible. As we can see in figure 4, our predicted savings rate also falls sharply after 1980 . While actual savings follow the predicted pattern, they fall somewhat before we predict the decline to take place. For the United States, as for many industrial countries, a slow rise in life expectancy and decline in youth dependency over the period is offset by rising old age dependency, giving a fairly stable level of predicted savings. While the actual savings rate in the United States was stable over the period, it was about 5 percentage points lower than our prediction.

\section{Conclusion}

Improvements in health and longevity are likely to have large impacts on life cycle behavior as people look forward to longer, healthier lives. In relation to savings behavior, a key issue is how improvements in health and longevity affect the length of the working life. Increases in longevity alone tend to increase the relative length of retirement, thereby increasing the need for retirement income and generating higher savings rates among the young. Improvements in health, however, lead to a more ambiguous effect on savings, because they can lead to longer working lives and postponed retirement.

Empirically the dominant effect of increased life expectancy appears to be higher savings rates. The inclusion of life expectancy into savings regressions not only improves the fit, but also allows us to explain the remarkable savings boom in East Asia, which is difficult to explain using a pure age structure effect model. In terms of our model, the savings effect occurs because the effect of increased longevity for retirement income outweighs the effect of improved health on the length of the desired working life, thereby 
increasing the need for retirement income. In practice, this effect is likely to be strongly influenced by institutional arrangements, such as legislation on retirement age and social security provisions. A more complete model would study how these institutional factors affect savings behavior. 


\section{References}

Asian Development Bank. 1997. Emerging Asia. Manila.

Berck, P., and K. Sydaeter. 1992. Economists' Mathematical Manual, $2^{\text {nd }}$ ed. Berlin: Springer-Verlag.

Bils, M., and P. Klenow. 2000. "Does Schooling Cause Growth?” American Economic Review 90: 1160-83.

Bloom, D., and D. Canning. 2000. "The Health and Wealth of Nations." Science 287: $1207-09$. . 2001. "Demographic Change and Economic Growth: The Role of Cumulative Causality." In Nancy Birdsall, Allen C. Kelley, and Steven Sinding, eds., Population Matters: Demographic Change, Economic Growth, and Poverty in the Developing World. New York: Oxford University Press.

Bloom, D., and J. Sachs. 1998. "Geography, Demography, and Economic Growth in Africa." Brookings Papers on Economic Activity 2: 207-73.

Deaton, Angus. 1992. Understanding Consumption. Oxford, U.K.: Oxford University Press.

Deaton, Angus, and Christina H. Paxson. 1993. "Savings, Growth, and Aging in Taiwan.” Working Paper no. 4330. National Bureau of Economic Research, Cambridge, Massachusetts. . 1997. "The Effects of Economic and Population Growth on National Savings and Inequality." Demography 34: 97-114. 
. 1998. "Growth, Demographic Structure, and National Savings in Taiwan."

Princeton University, Princeton, New Jersey. Processed.

Doshi, K. 1994. "Determinants of the Saving Rate—An International Comparison." Contemporary Economic Policy 12: 37-45.

Fogel, Robert W. 1994. "Economic Growth, Population Theory, and Physiology: The Bearing of Long-Term Processes on the Making of Economic Policy." American Economic Review 84: 369-95.

. 1997. "New Findings on Secular Trends in Nutrition and Mortality: Some Implications for Population Theory.” In Mark Rosenzweig and Oded Stark, eds., Handbook of Population and Family Economics, vol 1A. Elsevier.

Fry, M., and A. Mason. 1982. "The Variable Rate of Growth Effect in the Life-Cycle Model." Economic Inquiry 20: 426-42.

Gallup, J. L., J. D. Sachs, and A. Mellinger. 1999. “Geography and Economic Development." International Regional Science Review 22(2):179-232.

Higgins, M. 1998. "Demography, National Savings, and International Capital Flows." International Economic Review 39: 343-69.

Higgins M. and Williamson J. 1997. "Age Structure Dynamics in Asia and Dependence on Foreign Capital." Population and Development Review 23: 261-93.

Hurd, M., McFadden D. and Gan L. 1998. "Subjective Survival Curves and Life-Cycle Behavior," in David Wise (ed.): Inquiries in the Economics of Aging, University of Chicago Press, 259-305. 
International Economic Data Base (1997), available online at the Australian National University (http://iedb.anu.edu.au/).

Kalemli-Ozcan S., H. Ryder, and D. Weil. 1998. "Mortality Decline, Human Capital Investment, and Economic Growth.” Working Paper no. 98-18. Brown University, Department of Economics. Providence, Rhode Island.

Kalemli-Ozcan, S. and Weil D.N. 2002. "Mortality Change, the Uncertainty Effect, and Retirement," NBER Working Paper No.W8742.

Kelley, A. C., and R. M. Schmidt. 1996. "Saving, Dependency, and Development." Journal of Population Economics 9: 365-86.

Lee R. D., A. Mason, and T. Miller. 1998. “Saving, Wealth, and Population.” University of California at Berkeley. Processed.

. 2000. "Life Cycle Saving and the Demographic Transition in East Asia." Population and Development Review 26(Supplement): 194-222.

Lee R. and Tulijapurkar S. (1997), "Death and Taxes: Longer Life, Consumption, and Social Security," Demography, Vol. 34, pp 67-81.

Leff, Nathaniel H. 1969. "Dependency Rates and Savings Rates.” American Economic Review 59: 886-96.

Leung, S. F. 1994. "Uncertain Lifetime, the Theory of the Consumer, and the Life Cycle Hypothesis." Econometrica 62: 1233-39.

Mason, A. 1981. “An Extension of the Life-Cycle Model and its Application to Population Growth and Aggregate Saving." Working Paper no. 4. East-West Institute, Honolulu, Hawaii. 
. 1987. "National Saving Rates and Population Growth: A New Model and New Evidence." In D. G. Johnson and R. Lee, eds., Population Growth and Economic Development: Issues and Evidence. Madison, Wisconsin: University of Wisconsin Press. . 1988. "Saving, Economic Growth, and Demographic Change." Population and Development Review 14: 113-44.

. 1997. "Will Population Change Sustain the 'Asian Economic Miracle'?" Working Paper no. 33. East-West Institute, Honolulu, Hawaii.

Masson, P. R., T. Bayoumi, and H. Samiei. 1998. "International Evidence on the Determinants of Private Saving." World Bank Economic Review 12: 483-501.

Meltzer, D. 1995. "Mortality Decline, the Demographic Transition, and Economic Growth." Processed. University of Chicago.

Philipson, T. J., and G. S. Becker. 1998. "Old-Age Longevity and Mortality Contingent Claims." Journal of Political Economy 106: 551-73.

Strauss, J., and D. Thomas. 1998. "Health, Nutrition, and Economic Development." Journal of Economic Literature 36: 766-817.

Summers, R., and A. Heston. 1991. "The Penn World Tables (Mark 5): An Expanded Set of International Comparisons, 1950-1988." Quarterly Journal of Economics 106(2): 327-68.

Summers, R., and A. Heston. 1994. Penn World Tables, Mark 5.6 (website version). Philadelphia: University of Pennsylvania.

United Nations. 1998. Demographic Indicators 1950-2050. New York. 
World Bank. 1999. World Development Indicators 1999. Washington, D.C.

"Processed" refers to informally reproduced works that may not be available through libraries. 
Table 1

Definitions and Sources of Savings Rate Data

\begin{tabular}{|l|l|l|l|}
\hline $\begin{array}{l}\text { Savings Rate } \\
\text { Variable }\end{array}$ & \multicolumn{1}{|c|}{ Definition } & \multicolumn{1}{|c|}{$\begin{array}{c}\text { Years } \\
\text { Covered }\end{array}$} & \multicolumn{1}{c|}{ Source } \\
\hline GDS $_{\mathrm{N}}$ & $\begin{array}{l}\text { Gross domestic savings rate (in } \\
\text { constant local currency units) }\end{array}$ & $\begin{array}{l}1960-97 \\
\text { annual }\end{array}$ & $\begin{array}{l}\text { World Development Indicators } \\
1999\end{array}$ \\
\hline $\mathrm{GNS}_{\mathrm{I}}$ & $\begin{array}{l}\text { Gross national savings rate (in } \\
\text { constant local currency units) }\end{array}$ & $\begin{array}{l}1970-97 \\
\text { annual }\end{array}$ & $\begin{array}{l}\text { World Development Indicators } \\
1999\end{array}$ \\
\hline $\mathrm{GNS}_{\mathrm{II}}$ & $\begin{array}{l}\text { Gross national savings rate } \\
\text { excluding international transfer } \\
\text { payments (in constant local currency } \\
\text { units) }\end{array}$ & $\begin{array}{l}1960-97 \\
\text { annual }\end{array}$ & $\begin{array}{l}\text { World Development Indicators } \\
1999\end{array}$ \\
\hline
\end{tabular}




\section{Table 2}

Descriptive Statistics on Savings Rate Data

\begin{tabular}{|l|c|c|c|c|}
\hline $\begin{array}{l}\text { Savings Rate } \\
\text { Variables and } \\
\text { Number of Countries } \\
\text { and Observations }\end{array}$ & Mean & $\begin{array}{c}\text { Standard } \\
\text { Deviation }\end{array}$ & Maximum & Minimum \\
\hline $\begin{array}{l}\text { GDS }_{\mathrm{N}} \\
68 \text { countries } \\
410 \text { observations }\end{array}$ & 17.6 & 9.45 & 46.8 & -14.4 \\
\hline $\begin{array}{l}\mathrm{GNS}_{\mathrm{I}} \\
68 \text { countries } \\
300 \text { observations }\end{array}$ & 18.7 & 8.3 & & \\
\hline $\begin{array}{l}\mathrm{GNS}_{\mathrm{II}} \\
69 \text { countries } \\
413 \text { observations }\end{array}$ & 15.9 & 10.1 & & \\
& & & & \\
\hline
\end{tabular}




\section{Table 3}

Correlation Matrix of Savings Rates

\begin{tabular}{|l|c|c|c|}
\hline & $\mathrm{GDS}_{\mathrm{N}}$ & $\mathrm{GNS}_{\mathrm{I}}$ & $\mathrm{GNS}_{\text {II }}$ \\
\hline $\mathrm{GDS}_{\mathrm{N}}$ & 1.0 & & \\
\hline $\mathrm{GNS}_{\mathrm{I}}$ & 0.74 & 1.0 & \\
\hline $\mathrm{GNS}_{\mathrm{II}}$ & 0.97 & 0.79 & 1.0 \\
\hline
\end{tabular}




\section{Table 4}

Descriptive Statistics on Selected Regressors

\begin{tabular}{|l|c|c|c|c|}
\hline Variable & Mean & $\begin{array}{c}\text { Standard } \\
\text { Deviation }\end{array}$ & Maximum & Minimum \\
\hline $\begin{array}{l}\text { Life expectancy } \\
\text { (in years) }\end{array}$ & 62.7 & 11.1 & 79.5 & 22.6 \\
\hline $\begin{array}{l}\text { Youth share (population aged 0-19 } \\
\text { as share of total population) }\end{array}$ & 0.46 & 0.11 & 0.61 & 0.23 \\
\hline $\begin{array}{l}\text { Elderly share (population aged 60+ } \\
\text { as share of total population) }\end{array}$ & 0.09 & 0.05 & 0.24 & 0.04 \\
\hline \begin{tabular}{l} 
Log income per capita (PPP) \\
\hline $\begin{array}{l}\text { Liquid liabilities as a percentage of } \\
\text { GDP }\end{array}$
\end{tabular} & 7.90 & 1.01 & 9.78 & 9.35 \\
\hline $\begin{array}{l}\text { Rate of inflation, five-year average } \\
\text { based on GDP deflator (percent) }\end{array}$ & 15.7 & 26.2 & 215.1 & -2.79 \\
\hline $\begin{array}{l}\text { Annual average growth rate of } \\
\text { income per capita (PPP) over } \\
\text { previous decade (percent) }\end{array}$ & 1.97 & 2.30 & 9.45 & -4.16 \\
\hline
\end{tabular}

PPP Purchasing power parity. 


\section{Table 5}

Effects of Longevity on Savings, OLS Estimates

(dependent variable: gross domestic savings rate)

\begin{tabular}{|c|c|c|c|c|}
\hline \multirow[b]{2}{*}{ Variable } & \multicolumn{4}{|c|}{ Specification } \\
\hline & $\begin{array}{c}\text { (1) } \\
\text { Dummies for } \\
\text { each age } \\
\text { group }\end{array}$ & $\begin{array}{c}\text { (2) } \\
\text { Polynomial } \\
\text { age and } \\
\text { dependency } \\
\text { rate effects }\end{array}$ & $\begin{array}{c}\text { (3) } \\
\text { Polynomial } \\
\text { age effects }\end{array}$ & $\begin{array}{c}(4) \\
\text { Dependency } \\
\text { rate effects }\end{array}$ \\
\hline Life expectancy & $\begin{array}{l}0.339^{*} \\
(0.081)\end{array}$ & $\begin{array}{l}0.348^{*} \\
(0.076)\end{array}$ & $\begin{array}{l}0.282^{*} \\
(0.073)\end{array}$ & $\begin{array}{l}0.365^{*} \\
(0.057)\end{array}$ \\
\hline $\begin{array}{l}\text { Growth rate of income per } \\
\text { capita during preceding } \\
\text { decade }\end{array}$ & $\begin{array}{l}0.913^{*} \\
(0.198)\end{array}$ & $\begin{array}{l}0.932^{*} \\
(0.197)\end{array}$ & $\begin{array}{l}0.928^{*} \\
(0.199)\end{array}$ & $\begin{array}{l}0.948^{*} \\
(0.202)\end{array}$ \\
\hline Youth share of population & & $\begin{array}{l}-159.6^{*} \\
(53.63)\end{array}$ & & $\begin{array}{l}-80.40^{*} \\
(11.22)\end{array}$ \\
\hline Elderly share of population & & $\begin{array}{l}-129.1 \\
(124.2)\end{array}$ & & $\begin{array}{c}-155.1^{*} \\
(18.66)\end{array}$ \\
\hline Age effect: linear term & & $\begin{array}{c}13.61 \\
(27.56)\end{array}$ & $\begin{array}{l}62.22^{*} \\
(21.35)\end{array}$ & \\
\hline Age effect: square term & & $\begin{array}{l}-4.637 \\
(3.363)\end{array}$ & $\begin{array}{l}-6.489^{*} \\
(3.168)\end{array}$ & \\
\hline Age effect: cubic term & & $\begin{array}{c}0.228 \\
(0.148)\end{array}$ & $\begin{array}{c}0.173 \\
(0.129)\end{array}$ & \\
\hline Intercept & $\begin{array}{l}-14.09 \\
(7.452)\end{array}$ & $\begin{array}{c}58.86 \\
(39.37)\end{array}$ & $\begin{array}{c}-13.60^{*} \\
(6.758)\end{array}$ & $\begin{array}{l}42.63 * \\
(8.743)\end{array}$ \\
\hline Country fixed effects & No & No & No & No \\
\hline Time dummies & Yes & Yes & Yes & Yes \\
\hline Age dummies & Yes & No & No & No \\
\hline R-squared & 0.539 & 0.534 & 0.521 & 0.526 \\
\hline
\end{tabular}




\begin{tabular}{|l|c|l|l|l|}
\hline Null hypothesis & $\begin{array}{l}\text { Age effects } \\
\text { jointly zero }\end{array}$ & $\begin{array}{l}\text { Age effects } \\
\text { captured by } \\
\text { polynomial } \\
\text { and } \\
\text { dependency } \\
\text { variables }\end{array}$ & $\begin{array}{l}\text { Dependency } \\
\text { variables can } \\
\text { be excluded } \\
\text { from (2) }\end{array}$ & $\begin{array}{l}\text { Polynomial } \\
\text { can be } \\
\text { excluded from } \\
(2)\end{array}$ \\
F statistic (df) & $\begin{array}{c}0.34 \\
\text { F(17,385) }\end{array}$ & $\begin{array}{c}5.66^{*} \\
\mathrm{~F}(12,385)\end{array}$ & $\begin{array}{l}\mathrm{F}(2,396) \\
\mathrm{F}(3,396)\end{array}$ \\
\hline
\end{tabular}

* Denotes significance at the 5 percent level for a two-tail test.

Note: All the estimates in this table are based on an unbalanced panel of quinquennial data for 68 countries during 1960-94 (410 observations). Heteroskedasticity-consistent standard errors are reported in parentheses below coefficient estimates. 


\section{Table 6}

Effects of Longevity on Savings, OLS Estimates with Country Fixed Effects (dependent variable: gross domestic savings rate)

\begin{tabular}{|c|c|c|c|c|}
\hline \multirow[b]{2}{*}{ Variable } & \multicolumn{4}{|c|}{ Specification } \\
\hline & (1) & (2) & (3) & (4) \\
\hline Life expectancy & $\begin{array}{l}0.462^{*} \\
(0.088)\end{array}$ & $\begin{array}{c}0.455^{*} \\
(0.087)\end{array}$ & $\begin{array}{l}0.410^{*} \\
(0.093)\end{array}$ & $\begin{array}{l}0.459^{*} \\
(0.094)\end{array}$ \\
\hline $\begin{array}{l}\text { Growth rate of income per } \\
\text { capita during preceding } \\
\text { decade }\end{array}$ & $\begin{array}{l}0.713^{*} \\
(0.130)\end{array}$ & $\begin{array}{l}0.717^{*} \\
(0.126)\end{array}$ & $\begin{array}{l}0.716^{*} \\
(0.125)\end{array}$ & $\begin{array}{c}0.735^{*} \\
(0.141)\end{array}$ \\
\hline Youth share of population & & $\begin{array}{l}-80.41^{*} \\
(28.38)\end{array}$ & & $\begin{array}{c}-89.48^{*} \\
(11.07)\end{array}$ \\
\hline Elderly share of population & & $\begin{array}{l}-48.58 \\
(59.16)\end{array}$ & & $\begin{array}{c}-153.0^{*} \\
(22.44)\end{array}$ \\
\hline Age effect: linear term & & $\begin{array}{c}13.28 \\
(16.45)\end{array}$ & $\begin{array}{l}33.72 * \\
(14.25)\end{array}$ & \\
\hline Age effect: square term & & $\begin{array}{l}-1.234 \\
(2.223)\end{array}$ & $\begin{array}{l}-1.409 \\
(2.260)\end{array}$ & \\
\hline Age effect: cubic term & & $\begin{array}{c}0.006 \\
(0.096)\end{array}$ & $\begin{array}{l}-0.049 \\
(0.097)\end{array}$ & \\
\hline Country fixed effects & Yes & Yes & Yes & Yes \\
\hline Time dummies & Yes & Yes & Yes & Yes \\
\hline Age dummies & Yes & No & No & No \\
\hline R-squared & 0.886 & 0.883 & 0.880 & 0.882 \\
\hline
\end{tabular}




\begin{tabular}{|l|c|l|l|l|}
\hline Null hypothesis & $\begin{array}{l}\text { Age effects } \\
\text { jointly zero }\end{array}$ & $\begin{array}{l}\text { Age effects } \\
\text { captured by } \\
\text { polynomial } \\
\text { and } \\
\text { dependency } \\
\text { variables }\end{array}$ & $\begin{array}{l}\text { Dependency } \\
\text { variables can } \\
\text { be excluded } \\
\text { from (2) }\end{array}$ & $\begin{array}{l}\text { Polynomial } \\
\text { can be } \\
\text { excluded from } \\
(2)\end{array}$ \\
F statistic (df) & $\begin{array}{c}5.39^{*} \\
\mathrm{~F}(17,316)\end{array}$ & $\begin{array}{c}0.70 \\
\mathrm{~F}(12,316)\end{array}$ & $\begin{array}{c}3.34^{*} \\
\mathrm{~F}(2,327)\end{array}$ & $\mathrm{F}(3,327)$ \\
\hline
\end{tabular}

* Denotes significance at the 5 percent level for a two-tail test.

Note: All the estimates in this table are based on an unbalanced panel of quinquennial data for 68 countries during 1960-94 (410 observations). Heteroskedasticity-consistent standard errors are reported in parentheses below coefficient estimates. 
Table 7

OLS Estimates of Longevity on Savings: Nonlinear Specifications (dependent variable: gross domestic savings rate)

\begin{tabular}{|c|c|c|c|c|}
\hline \multirow[b]{2}{*}{ Variable } & \multicolumn{4}{|c|}{ Specification } \\
\hline & (1) & (2) & (3) & (4) \\
\hline Life expectancy & $\begin{array}{l}0.437^{*} \\
(0.073)\end{array}$ & $\begin{array}{l}0.447^{*} \\
(0.092)\end{array}$ & & \\
\hline $\begin{array}{l}\text { Life expectancy if greater than or } \\
\text { equal to } 65\end{array}$ & $\begin{array}{l}-0.035 \\
(0.020)\end{array}$ & $\begin{array}{c}0.007 \\
(0.016)\end{array}$ & & \\
\hline Life expectancy 35-40 & & & $\begin{array}{c}3.732 \\
(2.579)\end{array}$ & $\begin{array}{l}4.180 \\
(4.204)\end{array}$ \\
\hline Life expectancy $40-45$ & & & $\begin{array}{l}10.06^{*} \\
(1.582)\end{array}$ & $\begin{array}{l}8.217^{*} \\
(2.023)\end{array}$ \\
\hline Life expectancy $45-50$ & & & $\begin{array}{l}16.44^{*} \\
(1.552)\end{array}$ & $\begin{array}{l}11.72^{*} \\
(1.274)\end{array}$ \\
\hline Life expectancy 50-55 & & & $\begin{array}{l}19.38^{*} \\
(1.211)\end{array}$ & $\begin{array}{l}11.59^{*} \\
(1.632)\end{array}$ \\
\hline Life expectancy 55-60 & & & $\begin{array}{l}20.84^{*} \\
(1.176)\end{array}$ & $\begin{array}{l}13.76^{*} \\
(1.764)\end{array}$ \\
\hline Life expectancy 60-65 & & & $\begin{array}{l}19.77^{*} \\
(1.308)\end{array}$ & $\begin{array}{l}14.17^{*} \\
(1.994)\end{array}$ \\
\hline Life expectancy 65-70 & & & $\begin{array}{l}21.58^{*} \\
(1.313)\end{array}$ & $\begin{array}{l}15.98^{*} \\
(2.317)\end{array}$ \\
\hline Life expectancy 70-75 & & & $\begin{array}{l}21.52^{*} \\
(1.772)\end{array}$ & $\begin{array}{l}16.66^{*} \\
(2.590)\end{array}$ \\
\hline Life expectancy 75-80 & & & $\begin{array}{l}21.74^{*} \\
(1.958)\end{array}$ & $\begin{array}{l}15.92^{*} \\
(2.919)\end{array}$ \\
\hline $\begin{array}{l}\text { Growth rate of income per capita } \\
\text { during preceding decade }\end{array}$ & $\begin{array}{l}0.942^{*} \\
(0.204)\end{array}$ & $\begin{array}{r}0.733^{*} \\
(0.140)\end{array}$ & $\begin{array}{l}0.946^{*} \\
(0.204)\end{array}$ & $\begin{array}{l}0.651^{*} \\
(0.148)\end{array}$ \\
\hline Youth share of population & $\begin{array}{l}-84.76^{*} \\
(11.59)\end{array}$ & $\begin{array}{l}-87.58^{*} \\
(12.52)\end{array}$ & $\begin{array}{l}-95.08^{*} \\
(11.51)\end{array}$ & $\begin{array}{l}-97.66^{*} \\
(13.38)\end{array}$ \\
\hline Elderly share of population & $\begin{array}{l}-156.6^{*} \\
(18.68)\end{array}$ & $\begin{array}{l}-149.6^{*} \\
(12.52)\end{array}$ & $\begin{array}{l}-155.1^{*} \\
(19.08)\end{array}$ & $\begin{array}{l}-148.5^{*} \\
(27.20)\end{array}$ \\
\hline Intercept & $\begin{array}{l}41.62^{*} \\
(8.776)\end{array}$ & -- & $\begin{array}{l}52.97^{*} \\
(7.362)\end{array}$ & -- \\
\hline
\end{tabular}




\begin{tabular}{|l|c|c|c|c|}
\hline Country fixed effects & No & Yes & No & Yes \\
\hline Time dummies & Yes & Yes & Yes & Yes \\
\hline R-squared & 0.530 & 0.882 & 0.554 & 0.884 \\
\hline
\end{tabular}

* Denotes significance at the 5 percent level for a two-tail test. Intercept not reported in fixed effect models (columns (2) and (4).

Note: All the estimates in this table are based on an unbalanced panel of quinquennial data for 68 countries during 1960-94 (410 observations). Heteroskedasticity-consistent standard errors are reported in parentheses below coefficient estimates. 


\section{Table 8}

Growth Tilting, Income Effects, and Robustness Checks (dependent variable: gross domestic savings rate)

\begin{tabular}{|c|c|c|c|c|}
\hline \multirow[b]{2}{*}{ Variable } & \multicolumn{4}{|c|}{ Specification } \\
\hline & (1) & (2) & (3) & (4) \\
\hline Life expectancy & $\begin{array}{l}0.369^{*} \\
(0.059)\end{array}$ & $\begin{array}{l}0.192^{*} \\
(0.083)\end{array}$ & $\begin{array}{l}0.183^{*} \\
(0.188)\end{array}$ & $\begin{array}{l}0.349^{*} \\
(0.075)\end{array}$ \\
\hline $\begin{array}{l}\text { Growth rate of income per capita } \\
\text { during preceding decade }\end{array}$ & $\begin{array}{l}6.735^{*} \\
(2.027)\end{array}$ & $\begin{array}{l}0.889^{*} \\
(0.201)\end{array}$ & $\begin{array}{l}0.879^{*} \\
(0.229)\end{array}$ & $\begin{array}{l}1.091^{*} \\
(0.249)\end{array}$ \\
\hline Youth share of population & $\begin{array}{l}-52.08^{*} \\
(14.19)\end{array}$ & $\begin{array}{l}-71.32 * \\
(11.73)\end{array}$ & $\begin{array}{l}-69.85^{*} \\
(13.88)\end{array}$ & $\begin{array}{l}-84.47^{*} \\
(12.71)\end{array}$ \\
\hline Elderly share of population & $\begin{array}{l}-90.14^{*} \\
(25.99)\end{array}$ & $\begin{array}{l}-159.5^{*} \\
(18.69)\end{array}$ & $\begin{array}{l}-159.9^{*} \\
(21.74)\end{array}$ & $\begin{array}{l}-178.3^{*} \\
(21.11)\end{array}$ \\
\hline Youth share $\mathrm{x}$ income growth & $\begin{array}{l}-8.768^{*} \\
(3.320)\end{array}$ & & & \\
\hline Elderly share $\mathrm{x}$ income growth & $\begin{array}{l}-20.79^{*} \\
(7.050)\end{array}$ & & & \\
\hline Log GDP per capita (PPP) & & $\begin{array}{l}3.158^{*} \\
(0.955)\end{array}$ & $\begin{array}{l}3.354^{*} \\
(1.025)\end{array}$ & \\
\hline $\begin{array}{l}\text { Liquid liabilities as a percentage of } \\
\text { GDP }\end{array}$ & & & $\begin{array}{c}0.008 \\
(0.030)\end{array}$ & \\
\hline Rate of inflation & & & $\begin{array}{c}0.971 \\
(1.183)\end{array}$ & \\
\hline $\begin{array}{l}\text { Beta (effect of income on the } \\
\text { strength of the life cycle model) }\end{array}$ & & & & $\begin{array}{l}0.085^{*} \\
(0.034)\end{array}$ \\
\hline Intercept & $\begin{array}{l}23.49^{*} \\
(10.69)\end{array}$ & $\begin{array}{l}24.98^{*} \\
(10.13)\end{array}$ & $\begin{array}{l}22.97^{*} \\
(11.29)\end{array}$ & $\begin{array}{l}50.03^{*} \\
(10.51)\end{array}$ \\
\hline R-squared & 0.534 & 0.541 & 0.527 & 0.530 \\
\hline
\end{tabular}

* Denotes significance at the 5 percent level for a two-tail test.

PPP Purchasing power parity.

Note: All the estimates in this table are based on an unbalanced panel of quinquennial data for 68 countries during 1960-94 (410 observations) except for column (3), which is based on 66 countries during 1965-94 (365 observations). Heteroskedasticity-consistent standard errors are reported in parentheses below coefficient estimates. Beta is the coefficient in the interaction term $(1+$ Beta $\log (\mathrm{GDP} / \max (\mathrm{GDP})))$ that is multiplied by the rest of the reported model. 


\section{Table 9}

Effect of Longevity on Savings: Instrumental Variables Estimates (dependent variable: gross domestic savings rate)

\begin{tabular}{|c|c|c|c|c|c|}
\hline & & Specific & on (Variables & trumented) & \\
\hline Variable & $\begin{array}{c}\text { (1) } \\
\text { (Income } \\
\text { growth) }\end{array}$ & $\begin{array}{c}(2) \\
\text { (Income } \\
\text { growth, life } \\
\text { expectancy) }\end{array}$ & $\begin{array}{c}\text { (3) } \\
\text { (Income } \\
\text { growth) }\end{array}$ & $\begin{array}{c}\text { (4) } \\
\text { (Income } \\
\text { growth, } \\
\text { income level) }\end{array}$ & $\begin{array}{c}\text { (5) } \\
\text { (Income } \\
\text { growth, } \\
\text { income level) }\end{array}$ \\
\hline Life expectancy & $\begin{array}{l}0.598^{*} \\
(0.076)\end{array}$ & $\begin{array}{l}0.460^{*} \\
(0.126)\end{array}$ & $\begin{array}{l}0.637^{*} \\
(0.091)\end{array}$ & $\begin{array}{l}1.058^{*} \\
(0.426)\end{array}$ & $\begin{array}{l}0.631^{*} \\
(0.175)\end{array}$ \\
\hline $\begin{array}{l}\text { Growth rate of income per capita } \\
\text { during preceding decade }\end{array}$ & $\begin{array}{l}-1.405^{*} \\
(0.563)\end{array}$ & $\begin{array}{l}-1.283^{*} \\
(0.544)\end{array}$ & $\begin{array}{l}12.49^{*} \\
(3.752)\end{array}$ & $\begin{array}{l}-1.594^{*} \\
(0.692)\end{array}$ & $\begin{array}{l}-1.458^{*} \\
(0.630)\end{array}$ \\
\hline Youth share of population & $\begin{array}{l}-111.6^{*} \\
(15.83)\end{array}$ & $\begin{array}{l}-119.5^{*} \\
(16.43)\end{array}$ & $\begin{array}{l}-38.43 \\
(23.97)\end{array}$ & $\begin{array}{l}-138.5^{*} \\
(32.74)\end{array}$ & $\begin{array}{l}-114.8^{*} \\
(20.91)\end{array}$ \\
\hline Elderly share of population & $\begin{array}{l}-223.9^{*} \\
(29.03)\end{array}$ & $\begin{array}{l}-219.5^{*} \\
(28.51)\end{array}$ & $\begin{array}{l}-82.89 \\
(44.99)\end{array}$ & $\begin{array}{l}-222.8^{*} \\
(33.57)\end{array}$ & $\begin{array}{l}-237.7^{*} \\
(73.15)\end{array}$ \\
\hline Youth share $\mathrm{x}$ income growth & & & $\begin{array}{c}-22.32 * \\
(6.57)\end{array}$ & & \\
\hline Elderly share $\mathrm{x}$ income growth & & & $\begin{array}{l}-42.75^{*} \\
(13.34) \\
\end{array}$ & & \\
\hline Log GDP per capita (PPP) & & & & $\begin{array}{l}-7.804 \\
(7.065)\end{array}$ & \\
\hline $\begin{array}{l}\text { Beta (effect of income on the } \\
\text { strength of the life cycle model) }\end{array}$ & & & & & $\begin{array}{c}0.039 \\
(0.194) \\
\end{array}$ \\
\hline Intercept & $\begin{array}{l}49.26^{*} \\
(10.76)\end{array}$ & $\begin{array}{l}61.23^{*} \\
(13.80)\end{array}$ & $\begin{array}{l}-0.106 \\
(18.18)\end{array}$ & $\begin{array}{l}93.80^{*} \\
(44.04)\end{array}$ & $\begin{array}{l}50.76^{*} \\
(13.43)\end{array}$ \\
\hline R-squared & 0.349 & 0.349 & 0.338 & 0.229 & 0.360 \\
\hline
\end{tabular}

* Denotes significance at the 5 percent level for a two-tail test.

PPP Purchasing power parity.

Note: All the estimates in this table are based on an unbalanced panel of quinquennial data for 68 countries during 1960-94 (410 observations) except for column (3), which is based on 66 countries during 1965-94 (365 observations). Heteroskedasticity-consistent standard errors are reported in parentheses below coefficient estimates. Beta is the coefficient in the interaction term $(1+$ Beta $\log (\mathrm{GDP} / \max (\mathrm{GDP})))$ that is multiplied by the rest of the reported model.

Instrumental variables: Latitude, land area within $100 \mathrm{~km}$ of the coast or major waterway, percent of land area in the tropics. 


\section{Table 10}

Effects of Longevity on Alternative Savings Rate Measures, OLS Estimates With and Without Country Fixed Effects, and IV Estimates

\begin{tabular}{|l|c|c|c|}
\hline \multirow{2}{*}{ Savings Rate } & \multicolumn{3}{|c|}{ Coefficient of Life Expectancy } \\
\cline { 2 - 4 } & & & $\begin{array}{c}\text { IV } \\
\text { (income growth } \\
\text { instrumented) }\end{array}$ \\
\hline GDS $_{\mathrm{N}}$ & OLS & Fixed Effects & $0.631^{*}$ \\
(68 countries, & $0.365^{*}$ & $0.459^{*}$ & $(0.175)$ \\
\hline GNS $_{\mathrm{I}}$ & $(0.057)$ & $(0.094)$ & $0.159^{*}$ \\
$(68$ countries, & & & $(0.070)$ \\
300 observations) & $0.176^{*}$ & 0.077 & $0.554^{*}$ \\
\hline GNS $_{\text {II }}$ & $(0.065)$ & $(0.111)$ & $(0.077)$ \\
408 countries, & & & \\
\hline
\end{tabular}

* Denotes significance at the 5 percent level for a two-tail test.

Note: All the estimates are based on unbalanced panels of quinquennial data. The specifications include income growth, youth and elderly age shares, and time dummies. Heteroskedasticity-consistent standard errors are reported in parentheses below coefficient estimates. 


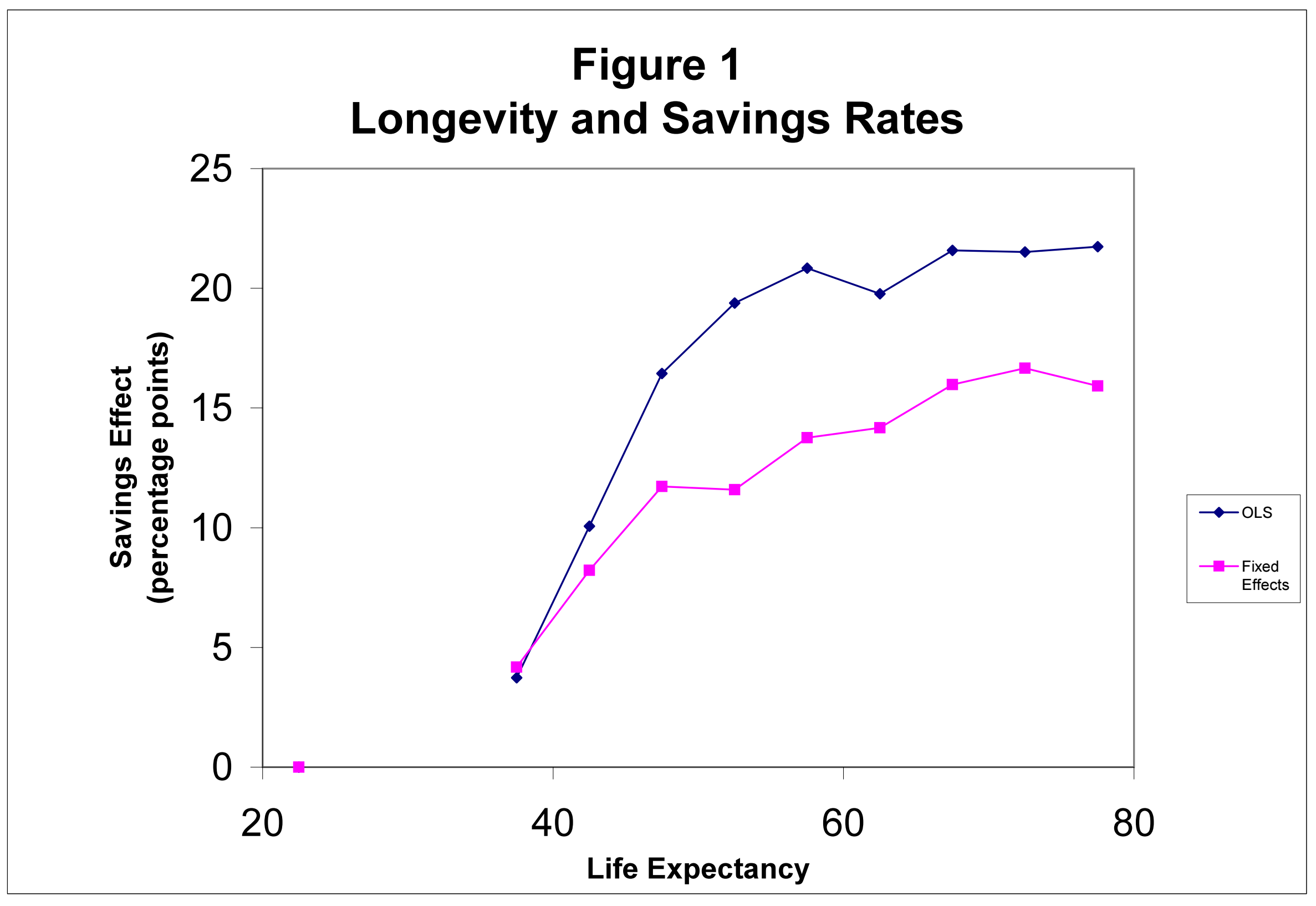




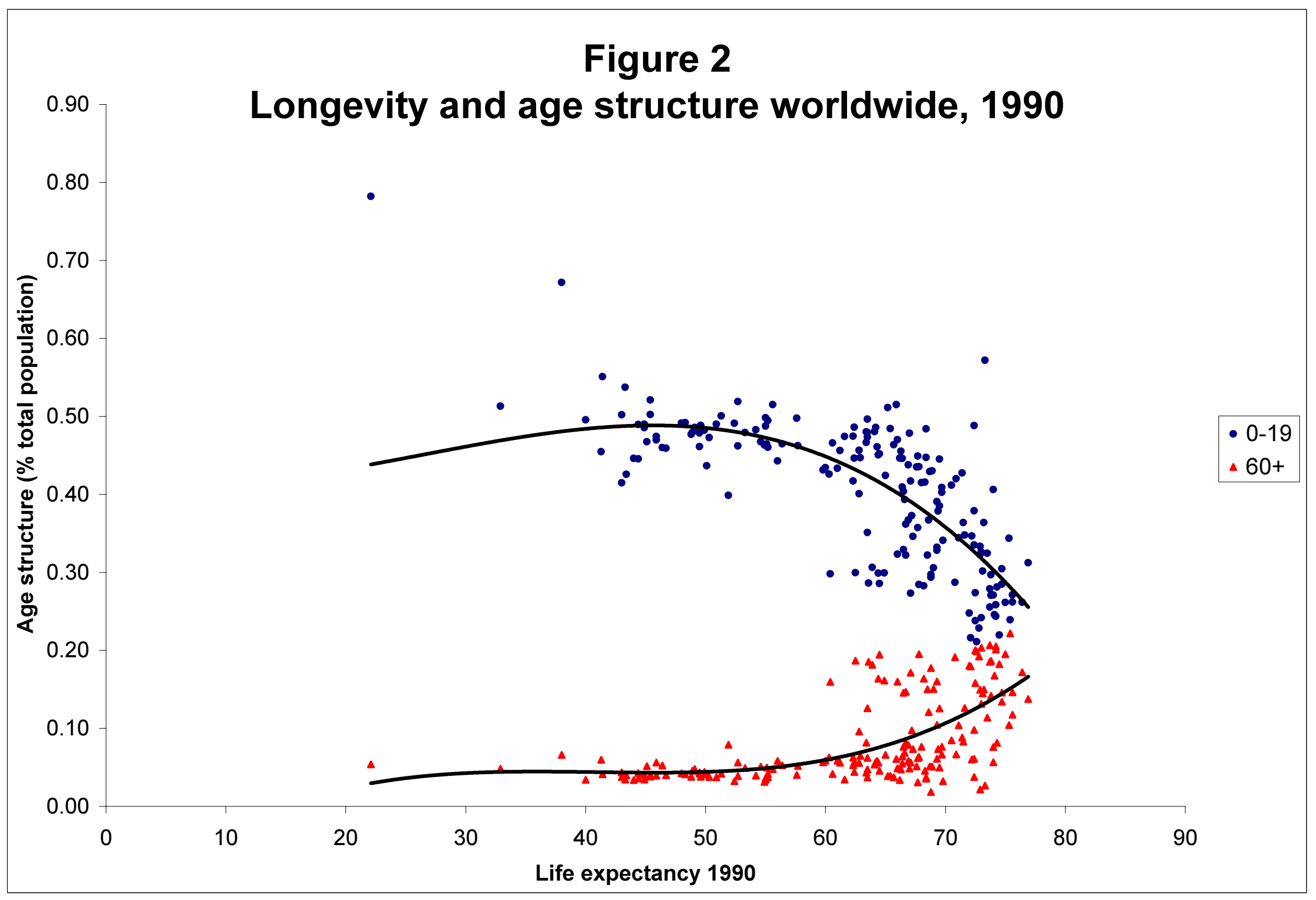


Figure 3

\section{Savings Rates 1990-1994}

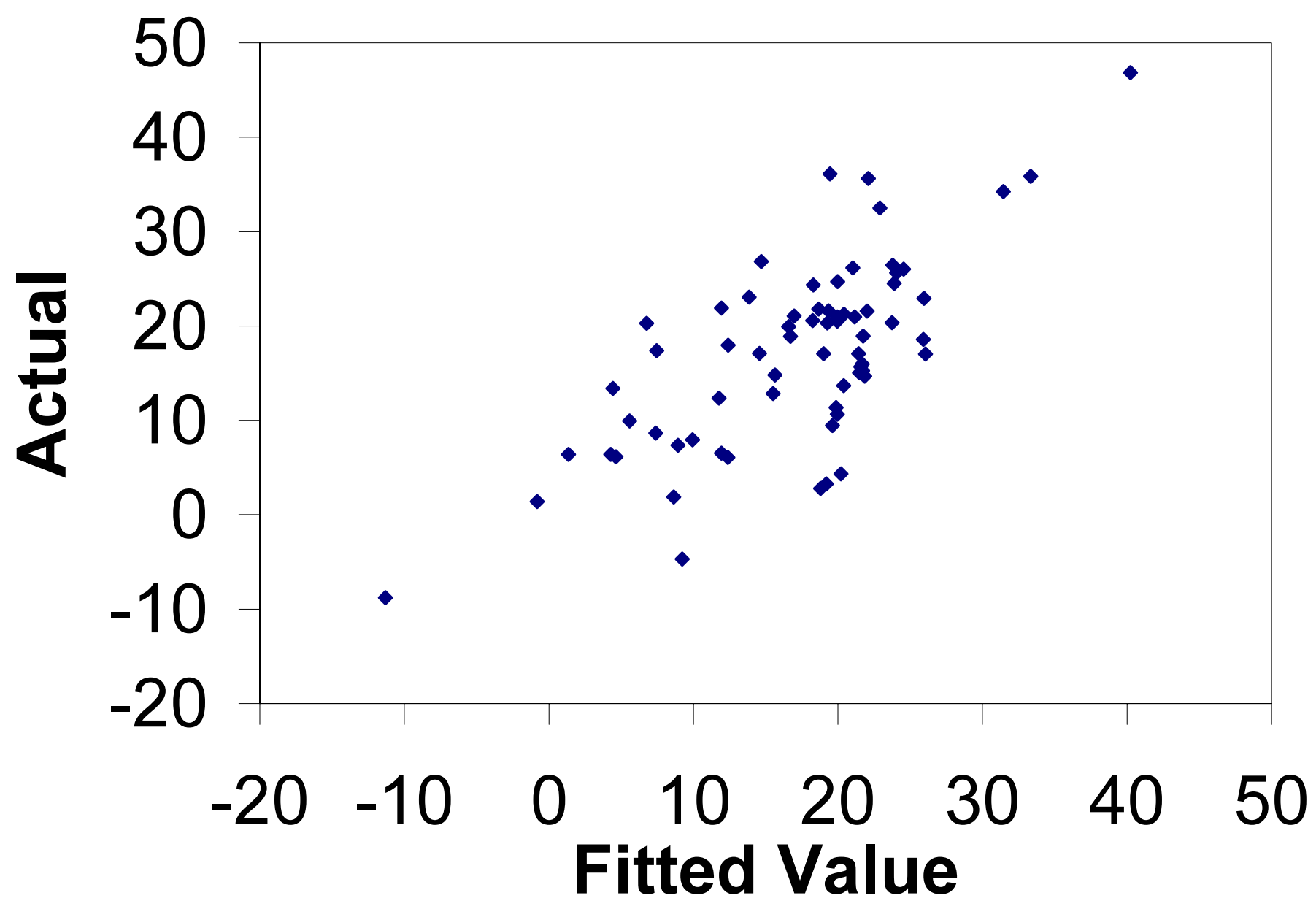




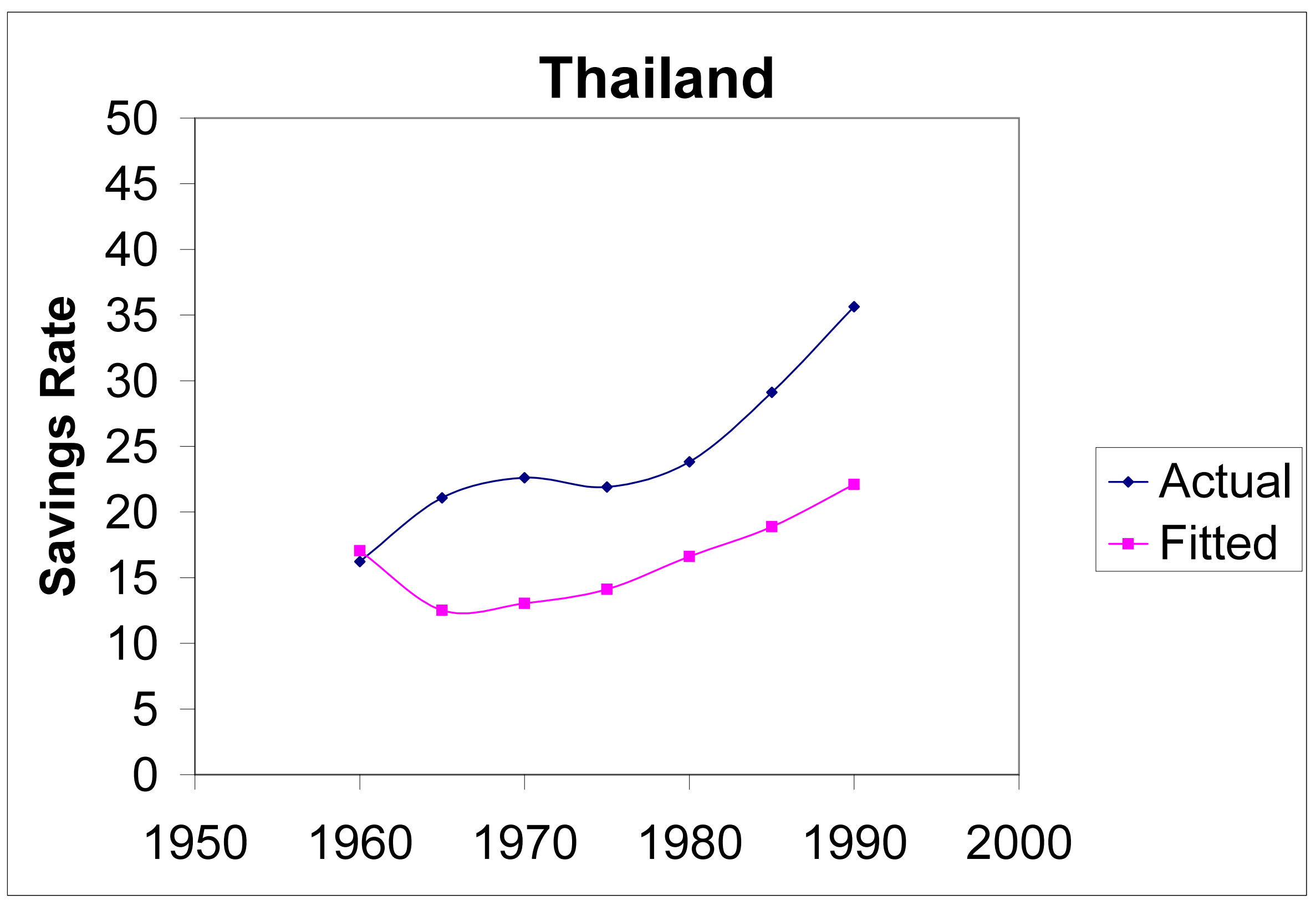

